\section{Carcass and the Meat Quality of Hungarian Lambs}

\author{
Györgyi Molnár - Zsófia Várszegi - András \\ Jávor \\ University of Debrecen, Centre of Agricultural Sciences, \\ Faculty of Agricultural Sciences, \\ Department of Animal Husbandry, Breeding and Nutrition, \\ Debrecen
}

\section{SUMMARY}

The author investigated 153 lambs of nine genotypes originating from breeding flocks, and 50 lambs originating from production flocks. The investigations were performed between 1995 and 1998. The authors discuss the evaluation of comformation and fat cover according to EUROP standards. The authors also investigate the proportion of valuable meat by genotype, and - out of the internal value indicators - the drymatter, protein, fat, connective-tissue and hemin contents comparing the flavour, aroma, tenderness, and oven loss of the different genotypes.

The following findings should be highlighted:

- The Hungarian Merino breed should be improved, as according to EUROP standards, more than $70 \%$ of these animals were rated as quality „ $R$ ”.

- Hungarian fattening technology has to be preserved, as the lambs reach the desired slaughter weight within a short period of time, and without over-fattening.

- Readiness for slaughter, typical of each genotype, has to be defined, and slaughter at proper weight be achieved.

- It has to be re-evaluated whether the Hungarian Merino is the only breed which can be used in Hungary, as none of the investigations really proved the special characteristics and significance of this breed. tables.

The author summarizes the findings of the investigation in five

\section{INTRODUCTION}

In Hungary, bony meat production per individual ewe is below 10 kilograms, which is 60 percent of the European average, and less than that of the Irish and the Dutch numbers. (The fact than we sell lambs in smaller quantities also plays a role in this number.)
In general, our products have no measurable or objective competitive advantage. We have information about such advantages primarily on the basis of the personal opinion of consumers (e.g.: special colour, flavour, look), but the actual competitive advantage of these characteristics is basically and increasingly dependant on the efficiency of marketing activities. At the same time, according to Udovecz (1998), it is also a fact that we do not have significant competitive disagvantages in terms of quality standards, either. Moreover, there are also some positive exceptions. Are these hyptheses supported by the objective and subjective quality parameters of domestic lamb?

\section{LITERATURE}

Fabregas et al. (1989) experienced that crossbreeding improves EUROP quality. Frederiksen et al. (1993) found that carcass conformation and fat cover improve with the application of the meat breed, while colour remains the same. However, the meat - fat ratio is clearly worsening, and the bone - lean meat ratio is worsening relatively (with $15 \%$ ). Conformation also gives a picture about the distribution of muscles within the carcass (Turner and Young, 1969). They concluded that lamb with better conformation tends to become fat more than lamb with worse conformation (Harrington and Kempster, 1989). In spite of this, there are repeated attempts to define the meaty nature of lamb on the basis of conformation. However, if the values of carcass formation are corrected with slaughter weight fattyness, then meat ratio can be estimated quite well.

Windsor (1994) found the following distribution in the case of the French flock:

\begin{tabular}{|l|r|r|r|r|r|r|r|r|r|r|r|r|}
\hline \multicolumn{1}{|c|}{ Breed } & E3L & E4L & U2 & U3L & U3H & U4L & R2 & R3L & R3H & O2 & O2L & O3H \\
\hline $\begin{array}{l}\text { Charmoise } \\
(18,3 \mathrm{~kg}) \mathrm{n}=32\end{array}$ & 3 & 3 & - & 47 & 6 & 3 & 3 & 22 & 9 & & - & - \\
\hline $\begin{array}{l}\text { Control group } \\
(19,4 \mathrm{~kg}) \mathrm{n}=96\end{array}$ & - & - & 1 & 9 & 1 & 1 & 26 & 48 & 6 & 3 & 3 & 1 \\
\hline
\end{tabular}

In the case of the control group, the maternity is milksheep, and the paternity is Suffolk, Charollais and Ile de France $F_{1}$ breeds.

Semi-carcasses of both Hungarian and French Merino lambs can only be classified - according to the EUROP slaughter-lamb classificastion - as either „R, O, P” qualities (Toldi et al., 1994). Molnár, A. (1996), who investigated the distribution of Dutch slaughtered lamb by meat quality, and compared these to that of the Hungarian Merino, also reached similar conclusions.

Unfortunately the quality distribution of Hungarian slaughtered lamb shows a significantly worse picture. The average quality of Merino falls into category „O”, and fat cover is also rather 3 , than the desirable 2 . 


\begin{tabular}{|c|c|c|c|c|c|c|c|c|c|c|}
\hline \multirow[t]{2}{*}{ Dutch flock } & \multicolumn{5}{|c|}{ Meat form (\%) } & \multicolumn{5}{|c|}{ Fat cover $(\%)$} \\
\hline & $\mathbf{E}$ & $\mathbf{U}$ & $\mathbf{R}$ & $\mathbf{O}$ & $\mathbf{P}$ & 1 & 2 & 3 & 4 & 5 \\
\hline Suckling lamb $(12-17 \mathrm{~kg})$ & & 43 & 54 & 3 & & 25 & 71 & 4 & & \\
\hline Grazing lamb $(21-24 \mathrm{~kg})$ & 2 & 57 & 39 & 2 & & 9 & 82 & 9 & & \\
\hline Lamb for breeding (26-28 kg) & 3 & 47 & 47 & 3 & & 10 & 74 & 100 & & \\
\hline
\end{tabular}

In the coming years, the percentage ratio and the quality of the slaughtered carcass will play an increasingly important role (Molnár and Jávor, 1996). Zezza et al. (1981) found the mutton production parameters of Merino very poor in their experiments, and this statement equally applies to intensity- and slaughter parameters. When comparing the German fattening- and test slaughter results with the data of the Hungarian Merino, it became clear that Hungarian Merino had worse results than those of the lambs which are equal with the German Merino, but were mutton Merinos and their crossbreeds with intensive meat breeds (Veress et al., 1984), (Bogner and Matzke, 1964).

As opposed to the $44.6 \%$ slaughter ratio of the Merino, the roughly $50 \%$ values of breeds with Suffolk paternity are also significant quality indicators. Lamb with Suffolk paternity have more favourable roast proportions, and better bone - meat ratio (Mihálka et al., 1983). Their findings proved the exceptional importance of Suffolk breed in mutton production and in meat quality.

The different adipose tissues of the ewe, like the tissues covering the abdominal cavity, stomach, mesentery, kidneys, and the intestine contain the largest quantity of fat, those making up $60 \%$ of all the quantity elements. The remaining fat is located largely in the tissues surrounding the heart, gullet, rectum, and testicles. In the majority, the adipose tissues covering the meat are consumed together with the meat. Fat content and fat composition of the tissues depend on the level of nutrition, the breed, the age of the animal, and on the climatic conditions (Lásztity and Törley, 1993). According to Aalhus and Price (1986), fat content of the meat increases with age. The above statement is especially true in the case of extensive fattening. Lovas (1986) found a correlation between fat production and the different fat contents (subcutinous, among the muscles).

It is probably the connective tissue which exerts the largest influence on the tenderness, or the toughness of the meat. The quality of meat is partly influenced by the quantity, and partly by the quality of the connective tissue. The relatively large amount of connective tissue - thick septums of connective tissue among the bunches of muscular fibre -, and connective tissue rich in collagene and poor in elastine result in harder, tougher, more chewy meat (Bíró and Százados, 1993). Fat is present in the meat in the form of adipose tissue. This can either be visible subcutinous fat, fat between the muscles (intermuscular fat), or fat within the muscles (intramuscular fat), appearing in marble form and shape. Lean meat contains $1-2 \%$ of fat. As a consequence of marbelization, this fat content may increase from $2 \%$ to even $10 \%$. As a result of adipose tissue among the muscles, fat content in the meat may increase to $20 \%$. However, we have to indicate that - to a limited extent - fat inside the muscles is desirable, because marbelized meat, in terms of flavour and tenderness, is better than less marbelized meat. In contrast to the generally accepted view that animal fat primarily contains saturated fatty acids, the truth is that roughly half of the fatty acids in the meat fat are unsaturated. In the case of the unsaturated fatty acids of aminal fats, simple unsaturated fatty acids are dominant, as multiple unsaturated fatty acids are present in large quantities in vegetable oils (O. Honikel, 1993).

Sanudo et al. (1992), (1997) concluded that eating habits, the accustomed quality and flavour considerably influence the market value of mutton, even beyond objective quality. Additionally Veress (1993) emphasized the decisive importance of oven loss (liquid-containment capability), and of tenderness among the characteristics which are taken into account. Marinova and Pinkas (1983), evaluating the relationship among the different meatquality characteristics concluded that there are different correlations between the $\mathrm{pH}$ value and the meat colour, tenderness and oven loss, and the colour and myoglobine content, or tenderness of meat. Myoglobine-content, according to their investigations, influences collagene content (negative), tenderness (positive), and oven loss (negative). For this reason, the above factors should be analysed together. As to total pigment content, a $1.3-2.95 \mathrm{mg} / \mathrm{g}$ extreme value was found in the case of Hungarian Merino (Veress et al., 1984). Eraso et al. (1982) found a correlation between the quality of the slaughtered carcass and the colour and leanness of the meat and fat. Incze et al. (1996) evaluated and summarized the finding of several researchers as to some factors influencing the fine quality of meat. The most significant measure toughness, tenderness, elasticity and the relationship between a decrease in $\mathrm{pH}$ value and tenderness. The meat of the longissimus dorsi shows the highest colour stability. The meat of lambs with high meat production is tough, due to higher capastaline-content. Characteristic features are very important also because the consumer is willing to pay for tender meat. Although it is generally accepted that proper meat flavour necessarily means some percentage of fat content, i.e. some sort of marbelization, Swedish researchers reached the conclusion that the above characteristics do not negatively change even in the case of low fat content (Sanudo et al., 1991). O'Halloran et al. (1994) found that deliciousness decreases parallel to the decrease of intramascular fat content: 
In the USA, an investigation carried out using consumers revealed that the majority felt the difference in tenderness, wanted tender meat, and also emphasize the significance of the investigations carried out in this issue (Bolemann et al., 1995).

According to Brown et al. (1996), the assessments of the consumers based on organoleptic tests concerning the tenderness of meat are considerably different from those of a professional committee, and are not dependant on any measurable mechanical characteristics of the meat. The work necessary for chewing plays a decisive role in the judgement of tenderness by the consumers.

Parallel with the increase of slaughter mass, the protein content, and the intramuscular fat content of the meat increases, the meat becomes darker, and its tenderness decreases (Bernt, 1991).

Temisan and Augustini (1986) indicated that the aroma, the liquid content, and the tenderness of meat increase as a result of larger intramuscular fat deposits. However, in this case, the area around the kidneys and the loin become more fatty, and the percentage of adipose tissues - especially those of the intramuscular and subcutinous ones - increases.

\section{MATERIALS AND METHODS}

The investigations covered the quality of meat, the proportion of roast, the proportion of tissues, the physiology and organolpetic characteristics of the meat. The investigated breeds were the following: production flock, Suffolk, Ile de France, German Mutton Merino, Hungarian Merino, Bábolna Tetra, Prolific Merino, British Milksheep, Prolific Merino $\mathrm{X}$ Texel $\mathrm{F}_{1}$.

In the course of the slaughter investigations, the following were evaluated:

- weight before slaughter

- warm weight after slaughter

- production ratio (volume of slaughtered carcass $/ \mathrm{kg} /$ X 100/ carcass volume before slaughter $/ \mathrm{kg} /$ )

- proportion of roast parts

- volume of fat in the abdominal cavity

- volume of kidney fat

According to S/EUROP qualification:

- EU carcass shape

- EU fat cover category

The physiological-, chemical-, and organoleptic parameters of meat, at he 12th vertebra spondy, in case of meat samples from $m$. longissimus dorsi:

- oven loss

- dry matter content

- crude fat content

- crude protein content

- total connective tissue content

- total pigment content

- chewiness, aroma, and flavour of meat

The slaughter was usually conducted at higher weights than the Hungarian norm, the reason beeing was willing to pay more for tender meat. These findings

the necessity to achieve conformity between the slaughtered carcasses and the standard of the EUROP qualification (slaughtered carcass weight over $12 \mathrm{~kg}$ ).

Before slaughter, each lamb was individually weighed. Slaughter and skinning was directly followed by measuring the volume of the warm slaughtered carcass (the head, the leg ends, and the internals were not, but the bony meat containing the kidneys, and the kidney were measured). Cutting was made - based on the recommendation of OMMI according to the Australian method, after 24-hour cooling. We measured the weight of the roast parts, and the volume of fat in the kidneys and in the abdominal cavity.

The carcasses were assessed on the day of slaughter, on the basis of ,decree No.16/1998 (IV. 3) Ministry of Agriculture of the Minister of Agriculture on the assessment and qualification of slaughter lamb after slaughter (S/EUROP), and on their qualification into commercial classes."(FM RENDELETE, 1998).

The meat samples were investigated in the Central Laboratory of DATE.

The meat samples were taken post mortem, after 24-hour cooling from place around $\mathrm{pH}$ measurement (From the region of the $12^{\text {th }}$ and $13^{\text {th }}$ backbone vertebra spondy, from $\mathrm{m}$. longissimus dorsi). Dry matter content, pigment content, and connective tissue content were measured from the homogenized sample. The meat dried at $60 \mathrm{C}^{\circ}$ was repeatedly homogenized, and the crude protein, and crude fat contents were measured from this material.

Dry matter content was defined on the basis of MSZ (Hungarian Standard) (No. 5874/4-80).

For the definition of L(-) hidroxiproline content, MSZ 5874/9-84, for the measurement of crude fat content MSZ. 5874-2/1985, and for the calculation of crude protein content MSZ 5874-8/1978 were used as guidelines, while the remaining values (total pigment, organoleptic) were defined according to the methods described in the leaflets of the Hungarian Research Institute of Meat Industry (Országos Húsipari Kutatóintézet) (Vadáné, 1975).

\section{RESULTS}

Conformity with EUROP qualification

EUROP qualification is used, or being introduced, increasingly in Europe, although some countries tried to hinder the introduction of EUROP qualification in the year 2000. For this reason, there are many arguments both for and against this qualification. Hungary is also prepared to qualify the slaughetered carcasses on the basis of the this methodology. A great number of investigations were already performed on the status of Hungarian lamb in this qualification system. Table No. 1 shows the results of qualifications made in three years. This 
work was done jointly by OMMI and our Department.

Ten per cent of the slaughtered stock - 7 genotypes - was categorized as „P”; this category has no market value. Somewhat more than $50 \%$ fell into category „O”; this category still does not meet market requirements. Thirty percent reached medium quality, namely category „R”, while $7.5 \%$ and $0.8 \%$ of the flock was classified as category „U”(good), and category „E”(excellent), respectively. Table 1: Percentile distribution of conformation based on EUROP

\begin{tabular}{|l|r|r|r|r|r|r|r|r|}
\hline \multicolumn{1}{|c|}{ Genotype } & n & $\begin{array}{c}\text { Warm carcass } \\
\text { weight }\end{array}$ & Average & E & U & R & O & P \\
\hline Producing flocks & 50 & 13,5 & $\mathrm{O}^{0 \downarrow}$ & 0 & 0 & 10,2 & 74 & 15,8 \\
\hline Hungarian Merino & 30 & 14,1 & $\mathrm{R}^{-\uparrow \uparrow}$ & 0 & 3,3 & 66,7 & 30 & 0 \\
\hline Prolific Merino & 10 & 13,0 & $\mathrm{R}^{0 \downarrow \downarrow}$ & 0 & 0 & 100 & 0 & 0 \\
\hline German Mutton Merino & 20 & 14,2 & $\mathrm{R}^{+\uparrow}$ & 0 & 40 & 55 & 5 & 0 \\
\hline Bábolna Tetra & 32 & 13,9 & $\mathrm{R}^{0 \downarrow}$ & 0 & 3,1 & 87,5 & 9,4 & 0 \\
\hline British Milksheep & 10 & 14,9 & $\mathrm{R}^{+\downarrow}$ & 0 & 40 & 60 & 0 & 0 \\
\hline Ile de France & 19 & 14,7 & $\mathrm{U}^{-\uparrow}$ & 5,3 & 63,2 & 31,6 & 0 & 0 \\
\hline Suffolk & 19 & 15,2 & $\mathrm{R}^{0 \downarrow \downarrow}$ & 0 & 105 & 63,2 & 26,3 & 0 \\
\hline Total & 190 & 14,2 & $\mathrm{R}^{0 \downarrow}$ & 0,8 & 7,5 & 30,6 & 51,3 & 9,8 \\
\hline
\end{tabular}

0;+; $\uparrow$ : refer to FM rendelet, 1998

Production flock represents an even worse quality, as close to $90 \%$ of them were classified as categories „P”and „O”.

Out of the breeding flock, the Ile de France breed is exceptional, as $68.5 \%$ of it is classified as „U” and „E”. This breed might be of interest for us also because it is very similar to the Merino breed in its look - thus it can be accepted by the breeder and the market easier -, and can be used as improvement breed in cross-breeding. The British Milksheep, and the German Mutton Merino also performed well, close to $60 \%$ of each breed was categorized as „R", and close to $40 \%$ as „U”(good). The results of Suffolk were surprising, as this is one of the best meat breeds of the world, but $63 \%$ was classified only as , $\mathrm{R}$ ” in this classification system, thus it was worse than the other mutton breeds. It is very likely that the reason of this poor performance lies in the qualification system, because - as elaborated by Dutch experts - the EUROP qualification system basically prefers the Texel, and the beltex breeds. (round forms, deep sizes), while the American Suffolk was breeded specifically for long trunk and long chops.
Thirty percent of the Hungarian Merino originating from the breeding flock fell into category „O”, and $66.7 \%$ into category „R", and only $3.3 \%$ of it was categorized as „U”. This fact in itself indicates the need for modernization.

\section{EUROP qualification: fat cover}

The other basic pillar of EUROP qualification is categorization by fat cover. The Hungarian breeds showed good results (Table No. 2), which is primarily due to our intensive technology. In this technology, lambs reach slaughter weight while they are young. Sixty-five percent of the investigated lambs were classified into category No. 2, which indicates expressedly good quality, while $18.6 \%$ of them were classified into category No. 3, which is still good. Only $4.8 \%$ of them have too little fat (category No. 1), and this low fat content does not protect the slaughtered body from drying out, while $12 \%$ of them was classified into the high fat cover category.

Table 2: Percentile distribution of fat cover based on EUROP

\begin{tabular}{|l|r|r|r|r|r|r|r|r|r|}
\hline \multicolumn{1}{|c|}{ Genotype } & $\mathbf{n}$ & $\begin{array}{c}\text { Total fat } \\
\mathbf{( \% )}\end{array}$ & $\begin{array}{c}\text { Subcutinous } \\
\text { fat (\%) }\end{array}$ & Average & $\mathbf{1}^{\mathbf{0}} \mathbf{1}^{+}$ & \multicolumn{1}{c|}{$\mathbf{2}$} & $\mathbf{3}^{-}$ & $\mathbf{3}^{\mathbf{0}} \mathbf{3}^{+}$ & $\mathbf{4}^{-}$ \\
\hline Producing flocks & 50 & 7,5 & 4,8 & $2^{+\downarrow}$ & 7,6 & 63,9 & 17,5 & 10,6 & 0,4 \\
\hline Hungarian Merino & 30 & 6,3 & 4,6 & $2^{+\downarrow}$ & 0 & 76,7 & 16,7 & 6,7 & 0 \\
\hline Prolific Merino & 10 & 11,4 & 8,1 & 3 & 0 & 40 & 20 & 40 & 0 \\
\hline German Mutton Merino & 20 & 6,3 & 4,0 & $2^{+\downarrow}$ & 0 & 70 & 20 & 10 & 0 \\
\hline Bábolna Tetra & 32 & 6,2 & 4,6 & $2^{+\downarrow}$ & 0 & 68,7 & 18,8 & 12,5 & 0 \\
\hline British Milksheep & 10 & 7,3 & 4,3 & $2^{+\downarrow}$ & 0 & 80 & 20 & 0 & 0 \\
\hline Ile de France & 19 & 6,9 & 5,0 & $2^{* \uparrow}$ & 0 & 47,4 & 26,3 & 26,3 & 0 \\
\hline Suffolk & 19 & 3,4 & 3,0 & $2^{+\uparrow \uparrow}$ & 0 & 63,2 & 26,3 & 5,3 & 5,3 \\
\hline Total & 190 & 5,7 & 4,8 & $2^{+\uparrow}$ & 4,9 & 64,5 & 18,6 & 11,5 & 0,5 \\
\hline
\end{tabular}

1, 2, 3, 4, 0;+; $\downarrow$ : refer to FM rendelet, 1998

The production flock breed fell into almost all the categories; $64 \%$ and $17.8 \%$ of them were categorized as excellent and good, repsectively (categories Nos. 2 and 3.), while $7.5 \%$ of them have poor fat cover, and $10 \%$ of them have fat cover. No poor fat cover was found among the breeding flock. Out of Ile de France 
lambs, 26.3\%, while out of Prolific Merino 40\% were categorized into categories 3 . and 4., which are not very favourable. Investigations carried out in Holland also indicated that good conformation is often coupled with higher fat cover.

in the case of the Suffolk flock, and was the highest in the case of Prolific Merino.

\section{Valuable meat parts}

Cutting was executed, in harmony with OMMI recommendation, according to the Australian method. Dressing percentage (Table No. 3) exceeded $52 \%$ in the case of British Milksheep, and Bábolna Tetra. (These breeds got good qualification also in the EUROP system.) The share of valuable meat parts (chop, long leg, shoulder) was exceptionally
If we compare fat cover with subcutinous fat, and the proportion of total fat (fat in the abdominal cavity and on the kidney surface), no clear correlation is found. Suffolk mutton carcass had the least subcutinous fat, while Prolific Merino had the most. The percentage share of total fat was also the lowest high in the case of Prolific Merino, as it almost reached $82 \%$, though the dressing percentage hardly exceeded $49 \%$. Suffolk had the lowest proportion of valuable meat parts, with medium dressing percentage. The proportion of less valuable meat parts (rib, neck, leg) was high in the case of British Milksheep and Suffolk (27.1, and 27.6\%, respectively), and the lowest in the case of Prolific Merino, and Hungarian Merino (18, and 18.9\%, respectively).

Table 3: Rates of different parts in case of Australian cutting

\begin{tabular}{|l|r|r|r|r|r|}
\hline \multicolumn{1}{|c|}{ Genotype } & $\mathbf{n}$ & \multicolumn{1}{c|}{$\begin{array}{c}\text { Weight at } \\
\text { slaughter (kg) }\end{array}$} & \multicolumn{1}{c|}{$\begin{array}{c}\text { Dressing } \\
\text { percentage (\%) }\end{array}$} & $\begin{array}{c}\text { Proportion of I. } \\
\text { class meat (\%) }\end{array}$ & $\begin{array}{c}\text { Proportion of II. } \\
\text { class meat (\%) }\end{array}$ \\
\hline Hungarian Merino & 30 & 28,3 & 47,5 & 81,1 & 18,9 \\
\hline Prolific Merino & 10 & 26,0 & 49,2 & 82,0 & 18,0 \\
\hline German Mutton Merino & 20 & 28,4 & 49,8 & 78,8 & 21,2 \\
\hline Bábolna Tetra & 32 & 27,4 & 50,9 & 74,4 & 25,6 \\
\hline British Milksheep & 10 & 28,7 & 52,0 & 80,8 & 27,1 \\
\hline Ile de France & 19 & 29,3 & 50,0 & 72,4 & 19,2 \\
\hline Suffolk & 19 & 30,5 & 49,7 & 77,5 & 27,6 \\
\hline Total & 140 & 28,4 & 49,9 & & 22,5 \\
\hline
\end{tabular}

Tissue composition (nutritional- physiological values)

This is basically defined by water-, fat-, and protein content. The water content of mutton may vary between $48-80 \%$, the protein content between $12-23 \%$, and the fat content between $5-40 \%$.
The meat of Prolific Merino had the highest drymatter content (30.8\%) (Table No. 4), while the meat of Suffolk had the lowest (26.08\%). Hungarian Merino also had a relatively low dry-matter content $(28.6 \%)$. The dry-matter content of the meats of production flock was somewhat higher, while that of the breeding Merino was somewhat lower.

Table 4: Tissue composition of loin in breeds

\begin{tabular}{|c|c|c|c|c|c|c|}
\hline Genotype & $\mathbf{n}$ & $\begin{array}{c}\text { Dry matter } \\
(\%)\end{array}$ & $\begin{array}{c}\text { Crude protein } \\
(\%) \\
\end{array}$ & $\begin{array}{c}\text { Crude fat } \\
(\%)\end{array}$ & $\begin{array}{l}\text { Connective } \\
\text { tissue (\%) }\end{array}$ & $\begin{array}{l}\text { Hemin } \\
(\mathrm{mg} / \mathrm{g})\end{array}$ \\
\hline Producing flocks & 50 & 29,1 & 17,3 & 8,1 & 1,0 & 2,4 \\
\hline Hungarian Merino & 30 & 28,6 & 19,6 & 5,3 & 1,1 & 1,9 \\
\hline Prolific Merino & 10 & 30,8 & 22,2 & 7,8 & 1,1 & 2,0 \\
\hline German Mutton Merino & 20 & 29,7 & 21,0 & 5,8 & 1,0 & 1,7 \\
\hline Prolific Merino X Texel $F_{1}$ & 6 & 27,6 & 20,0 & 6,3 & 0,7 & 2,04 \\
\hline Bábolna Tetra & 32 & 28,9 & 20,6 & 5,3 & 0,7 & 2,5 \\
\hline British Milksheep & 10 & 29,1 & 18,2 & 5,0 & 0,9 & 2,0 \\
\hline Ile de France & 19 & 29,7 & 21,3 & 5,7 & 0,8 & 1,6 \\
\hline Suffolk & 19 & 26,1 & 19,1 & 4,3 & 1,0 & 2,9 \\
\hline Total & 196 & 28,8 & 19,9 & 5,6 & 0,9 & 2,2 \\
\hline
\end{tabular}

Meat also contains, albeit in lower quantities, vitamins and minerals, although it should primarily be considered as a source of protein. Protein of the muscle tissues are full value. We have to note that the amino-acid composition of mutton is extremely favourable.

The highest protein content $(22.15 \%)$, and - at the same time - almost the highest fat content (7.8\%) was found in the case of Prolific Merino. The lowest protein content $(17.25 \%)$ was found in the case of production flock. The protein content of British Milksheep was also low (18.2\%).

Fat content is also of great importance, as the purpose of breeding is to produce meat with low fat content. New-born lamb contains roughly 5\% fat, while fattened, fully grown lamb may contain more 
than $40 \%$ fat. In the course of fattening, thighs become the least fatty, followed by the shoulders, and the neck, while the backbone, and especially the ribs, not to speak about the thin flank really become fatty. Meats of production flock proved to be the most fatty $(8.1 \%)$, while Suffolk had the least fatty meat $(4.3 \%)$ (the proportion of subcutinous fat and

the quality of the connective tissues determine the tenderness of meat.

The proportion ratio of this less valuable protein was the lowest in Bábolna Tetra and in the crossbreeding of Prolific Merino with Texel, and was the highest in the case of Prolific Merino, and Hungarian Merino. The connective tissue content of the German Mutton Merino, the Suffolk, and the production flock was only somewhat lower.

The colour of the meat plays an especially important role when judging the quality of meat, because this is such a significant criteria which is used by the customers when buying meat. The customers relate freshness and flavour to a proper colour, although the relationship between these charateristics and the colour is not clear.

The colour of the meat is determined by the quantity of pigment, the quality of pigment, the watery nature of the meat, and the marblization of the surface.

Besides myoglobine, the colour of the meat is also influenced by the hemoglobine remaining in the meat. However, this becomes a significant factor only in the case of insufficient bleeding. The colour of the meat is also influenced by the quantity, colour, and distribution of the connective tissue, and of the adipose tissue.

The lowest hemine content, namely the lightest colour was found in the case of Ile de France flock, while Suffolk had the highest hemine content. The meat of Bábolna Tetra and of the cross-breeding of Prolific Merino with Texel is relatively dark.

Organoleptic and cooking -technological properties

Fat cover, the quantity of fat in the abdominal cavity, subcutinous fat content, and the quality of fat influence the flavour and the smell of mutton. The proportion of free fatty acids with different melting point define the typical smell of mutton. In young animals and among the muscles, fat is of low melting total fat was also the most favourable in the case of Suffolk breed).

Protein content of the connective tissue is the total of the collagene, and elastine contents of the sinew, the sinew membrane, and of the other connective tissues. Its nutrition value, as compared to the muscle protein, is significatnly lower. The composition

and point, while in older animals, especially in rams, the subcutinous fat and the fat in the abdominal cavity it is of higher melting point, thus its flavour is also more characteristic.

The Hungarian Merino and the lamb from Hungary is considered to be preferred due to its aroma. Though the research results showed considerable dispersion and variation, the above statement was not supported.

Bábolna Tetra had the best aroma (Table No. 5), while Prolific Merino cross-bred with Texel had the least odour. The meat of Suffolk was the most delicious, while that of the Prolific Merino crossbred with Texel was the least delicious.

The significance of tenderness does not have to be emphasized. Tenderness is the result of two main components: the feeling at the beginning of chewing, when teeth deepen into the meat, and the effort to chop, or chew the meat.

Tenderness means that the meat is crushed and crumbled with little chewing effort. Tenderness is always defined in the case of boiled or fried meat, with an instrument or sensually, by a committee. The size of the muscle fibres, the content of the connective tissue, and the fat content define tenderness.

The meat of the British Milksheep was the least tough (Table No. 5), while that of the German Mutton Merino was the toughest.

From the point of view of processing in the kitchen, good water containment, which is characterized by a dry cutting surface, non-shrinking during frying, and good packaging, is the most important characteristic.

Unfortunately dripping meat liquid also results in a protein loss of approximately $3-10 \%$.

Suffolk had the smallest oven loss, while Prolific Merino cross-bred with Texel had the largest oven loss. Hungarian Merino was not too good in any of the categories.

Table 5: Organoleptic and cooking technological properties

\begin{tabular}{|l|r|r|r|r|r|}
\hline \multicolumn{1}{|c|}{ Genotype } & n & \multicolumn{1}{c|}{ Smell } & \multicolumn{1}{c|}{ Taste } & \multicolumn{1}{c|}{ Toughness } & Oven loss (\%) \\
\hline Hungarian Merino & 30 & 1,42 & 1,89 & 2,41 & 22,1 \\
\hline Prolific Merino & 10 & 1,44 & 1,87 & 2,47 & 21,2 \\
\hline German Mutton Merino & 20 & 1,45 & 2,03 & 2,85 & 19,9 \\
\hline Prolific Merino X Texel F & 6 & 1,96 & 2,42 & 2,75 & 23,5 \\
\hline Bábolna Tetra & 32 & 1,33 & 1,82 & 2,59 & 20,8 \\
\hline British Milksheep & 10 & 1,54 & 2,24 & 2,24 & 18,4 \\
\hline Ile de France & 20 & 1,50 & 1,87 & 2,65 & 21,9 \\
\hline Suffolk & 19 & 1,34 & 1,75 & 2,65 & 14,8 \\
\hline Total & 153 & 1,50 & 1,98 & 2,57 & 20,9 \\
\hline
\end{tabular}




\section{REFERENCES}

Aalhus, J. L.-Price, M. A. (1986): Agriculture and Forestry Bulletin, 38-40.

Bernt Bech, A. (1991): 42. Eaap, Rostock In: Szűcs, E.: Nemzetközi szimpózium a hasított marha és a marhahús minősítéséröl. A Hús, 1992/1. 45-47.

Bíró, G.-Százados, I. (1993): Húshigiénia, húsvizsgálat. In: Élelmiszer-higiénia. Agroinform Kiadó és Nyomda Kft., Szerk.: Bíró, G.

Bogner, H.-Matzke, P. (1964): Fleischkunde für Tierzüchter Verlag BLG Gesellschaft, München - Basel - Wien, 77-78.

Bolemann, S. J. et al. (1995): Ismert porhanyóságú marhahúsok fogyasztói értékelése. A Hústudomány és Technológia 41. Nemzetközi Kongresszusa, In: Hús 1996/1. 7-26.

Brown, W. E. et al. (1996): Hogyan bírálják a fogyasztók a hús porhanyósságát? Az érzékszervi értékelésre ható tényezők. Technológia 42. Nemzetközi Kongresszusa, In: Csapó, I.Erdős, Z.-Incze, K.-Incze, Z.-Körmendy, L.-Mihályi, Gy-néVadáné Kovács, M.-Zukál, E.: Beszámoló a Hústudomány és Technológia 42. Nemzetközi Kongresszusáról. Hús 1997/1. 12-31.

Eraso, E.-Cabrero, M.-Garcia, D. E.-Siles, J. L. (1982): Some aspects of carcass grading and characters in sheep. Anales del Instituto Nacional de Investigaciones Agrarias, Ganadera, 13. 27-31.

Fabregas, X.-Torre, C.-Caja, G.-Casals, R.-Rivas, F. (1989): Comparison of carcasses of Ripollesa, Precoce X Ripollesa, German Mutton Merinó X Ripollesa lambs slaughtered at light and heavy body weights. Agriculture, EUR-Publication, 383388.

Frederiksen, J. H.-Kristensen, H.-Sugana, N. (1993): Preparing heavy-breed culled ewes for slaughter. Reports and Experiments in Sheep Production, 1. 93-95.

Harrington, G.-Kempster, A. J. (1989): Improving lamb carcass composition to meet modern consumer demand In: Reproduction, growth and nutrition in sheep. Edited by O.R. Dyrmundson and $\mathrm{S}$. Thorgeirsson, Iceland

Incze, K.-Klosz, T.-Kora, M.-Vadáné Kovács, M.-Mihályi, Gy-néRékasi, K-né (1996): A Hús. 1. 7-26.

Lásztity, R.-Törley, D. (1993): Élelmiszer-kémia 2. Szerk.: Gasztonyi, K.-Lásztity, R., Mezőgazda Kiadó, Budapest, 543.

Lovas, L. (1986): Genetikai és környezeti tényezők hatása a juh vágóértékére. Kandidátusi értekezés, Kaposvár, 116.

Marinova, P.-Pinkas, A. (1983): Variation of some meat quality characters in sheep. Zhivotnov dni Nauki 20. 8. 39-44.

Mihálka, T.-Molnár, A.-Schuszter, T. (1983): J-ÁKI hibridvégtermék hizlalási és vágási eredményeinek vizsgálata. Az Állattenyésztési és Takarmányozási Kutatóközpont Közleményei, Gödöllő, 277-281.

Molnár, A. (1996): Termelésszervezés magas fokon. A gazdaságos juhtenyésztés és termék-elöállitás feltételei. Szaktanácsadási füzetek 4. Állattenyésztési és Takarmányozási Kutatóintézet, Herceghalom, 48-54.
Molnár, Gy.-Jávor, A. (1996): Juhtenyésztés az EU integráció jegyében. Integráció az agrárgazdaságban, Keszthely, 417426.

O. Honikel, K. (1993): A hús jelentősége a táplálkozásban. A hús, 2. 71-74.

O'Halloran, G. R. et al. (1994): A végső pH hatása a hús porhanyósodására. In: Incze, K.-Incze, Z.-Vadáné Kovács, M.: A hús, 1995/2. 68-100.

Sanudo, C. et al. (1991): Könnyủ vágott juh húsának érzékszervi tulajdonságai. In: Csapó, I.-Incze, K.-Rékási K-né-Vadáné Kovács, M.: A Hús, 1992/4199-213.

Sanudo, C.-Delfa, R.-Gonzalez, C.-Casas, M.-Santolaria, P.-Vigil, E. (1992): Meat Quality of light lambs. ITEA, Production Animal. 88A. 3. 221-227.

Sanudo, C.-Nute, G.-Campo, M. M.-Maria, G.-Wood, J.-Sierra, I.Enser, M.-Baker, A. (1997): Sensory meat quality in light and medium weight lamb carcassees. Comparison between British and Spanish sensory panels. $43^{\text {rd }}$ ICOMST, New-Zealand

Temisan, V.-Agustini, C. (1986): Jahresb. Bundesanstalt Fleischforsch., Kulmbach

Toldi, Gy.-Rózsahegyi, P.-Molinári, A. (1994): Mesterségük címere: az EUROP vágójuh minősítés. Látogatás Franciaország legnagyobb juhvágóhídján. A Hús, 3. 161-164.

Turner, H. N.-Young, S. S. Y. (1969): Quantitative genetics in sheep breeding, Macmillan of Australia, 6-7.

Udovecz, G. (1998): A magyar állattenyésztés adottságai és esélyei az európai integrációban. A Hús, 1. 52-54.

Vadáné Kovács, M. (1975): Országos Húsipari Kutatóintézet füzetei. 4. Budapest

Veress, L. (1993): Juhtenyésztés fejlesztésének genetikai és tartástechnológiai kérdései. Akadémiai doktori értekezés. Budapest, 202.

Veress, L.-Vadáné Kovács, M.-Lovas, L.-Vágvölgyi, O.-Radnai, L.-Makay, B. (1984): Gyorshizlalású pecsenyebárányok hústermelő képességének és húsminőségének vizsgálata. I. A magyar merinó fajtában. Állattenyésztés és Takarmányozás, 33. $1.57-67$.

Windsor, J. (1994): The Charmoise returns. The Sheep Farmer, 14.

Zezza, L.-Muscio, A.-Crollo, R.-Nicastro, F. (1981): Area of the fibres of the longissimus dorsi muscle and relationship with carcass and meat quality in sheep. Rivista di Zootecnia e Veterinaria. 10. 5. 315-320.

FM rendelet (1998): A földmüvelésügyi miniszter 16/1998 (IV. 3) FM rendelete a vágójuhok vágás utáni minősítéséről (S/EUROP) és kereskedelmi osztályba sorolásáról. Magyar Közlöny, 29. 2474-2477.

MSZ. 5874/2-85: Húskészítmények vizsgálati módszerei. Zsírtartalom meghatározása

MSZ. 5874/4-80: Húskészítmények vizsgálati módszerei. Szárazanyag- és víztartalom meghatározása

MSZ. 5874/8-78: Húskészítmények vizsgálati módszerei. Fehérjetartalom meghatározása

MSZ. 5874/9-84: Húskészítmények vizsgálati módszerei. L(-) hidroxiprolin tartalom meghatározása 